Cadernos de Clio, Curitiba, n. ${ }^{\circ}$ 4, 2013

\title{
SILVA, S. C. Magia e Poder no Império Romano: A Apologia de Apuleio. 1. Ed. São Paulo: Annablume/FAPESP, 2012. 213p.
}

Filipe Cesar da Silva ${ }^{1}$

Semíramis Corsi Silva, autora do livro, é Doutoranda, Mestre e Graduada em História pela Universidade Estadual Paulista - UNESP/Franca, onde defendeu a Dissertação de Mestrado: Relações de Poder em um Processo de Magia no século II d.C - uma Análise do Discurso "Apologia” de Apuleio, do qual este livro é fruto.

A obra foi lançada ano passado (Marco/2012), em uma parceria da editora Annablume com a Fundação de Amparo à Pesquisa do Estado de São Paulo (FAPESP), do qual Silva é bolsista desde sua Iniciação Científica até seu Doutorado, que está em andamento. O livro possui 213 páginas, divididos em quatro capítulos, mais as considerações finais; a autora indaga e elucida sobre a acusação e o julgamento de Apuleio, um autor romano do século II d.C., por prática de magia. É nesse contexto que Silva propõe analisar a acusação e julgamento de Apuleio, um membro da elite do Império Romano no período do Principado, que se casou com uma rica viúva chamada Pudentila da cidade de Oea, no norte da África Romana.

O casamento se concretizou através de uma "negociação" do filho mais velho de Pudentila, Ponciano, que era amigo de Apuleio. Pudentila

\footnotetext{
${ }^{1}$ Graduando em História pela Universidade do Sagrado Coração - USC - Bauru/SP. Resenha realizada sob a orientação da $\operatorname{Prof}^{\mathrm{a}} \operatorname{Dr}^{\mathrm{a}}$ Lourdes Madalena Gazarini Conde Feitosa.
} 
esteve prometida em casamento a seu cunhado Sicinio Claro (irmão de seu falecido marido), mas acabou casando-se com Apuleio, por intermédio de Ponciano. Após dois anos do conúbio e Ponciano já falecido, Apuleio é acusado pelo filho mais novo de Pudentila, Pudente (irmão de Ponciano, enteado de Apuleio), de ter praticado magia amorosa para conquistar Pudentila, interessado em sua situação financeira. Pudente teve como seu assessor Sicínio Emiliano (tio do acusador e irmão do Sicinio Claro e do falecido marido de Pudentila). A família de seu marido falecido era formada por membros da elite local da cidade de Oea. Quem moveu a ação contra Apuleio foi Emiliano, irmão do falecido marido de Pudentila. Porém, a acusação foi feita em nome do filho mais novo da viúva, Pudente, que não tinha ainda maioridade jurídica e foi assessorado pelo tio.

Visto que o casamento era algo de extrema importância política nesse contexto, servindo como forma de estabelecer alianças entre famílias e sendo fundamental para a carreira de homens públicos, é que podemos contextualizar o enredo que envolve Apuleio, um filósofo aristocrático, adepto ao médio-platonismo, orador, romancista, advogado, decurião e escritor de diversas obras literárias, entre elas o principal objeto de estudo que a autora se propõe a investigar: a obra "Apologia”. Esta fonte documental consiste na transcrição da autodefesa do filósofo, redigida anos mais tarde do desenrolar do processo do qual foi acusado.

Como principal objetivo em sua pesquisa, a autora procura romper com os paradigmas e as visões reducionistas a respeito do mundo simbólico e religioso das sociedades antigas, analisando os motivos, as razões e os conflitos pelos quais o filósofo teria sido acusado e relacionando estes 
com as questões de disputa e relações de poder que envolvem Apuleio e os acusadores.

Para melhor explicitar sobre como a autora desenvolveu sua pesquisa, na qual o livro é resultado, será apresentada uma síntese de cada capitulo e a proposta que a autora estabelece em cada um deles, através de sua investigação e análise.

No primeiro capítulo denominado: Em Torno de Apuleio, a autora nos apresenta aspectos biográficos de Apuleio que, como a maioria das biografias da antiguidade clássica, há controvérsias sobre seu nascimento, origem e posterior falecimento. O capitulo é dividido em subtítulos que ressaltam a vida e as obras de Apuleio, sua trajetória como um homem público, seu contexto político-geográfico-cultural e a opulência dos personagens que figuram na obra analisada (Apologia), no qual a autora considera estes fatores determinantes para compreender a posição do sujeito na sociedade romana e suas relações de poder.

Em O Discurso Apologia e a Historiografia, segundo capítulo do livro, a autora dedica-se a analisar a obra literária Apologia e inicia uma discussão historiográfica acerca do processo de magia. Ao analisar o discurso Apologia, a autora verifica alguns aspectos do discurso, tais como, possível datação da escrita da fonte, razões da elaboração da obra, denominação do discurso, modificações do discurso pronunciado para o discurso escrito. Em seguida, realiza uma discussão historiográfica a respeito do tema, onde é possível compreender as novas indagações, as críticas feitas à historiografia corrente sobre o tema, as lacunas apontadas nos estudos já realizados e a contribuição de sua pesquisa. 
No terceiro capítulo, Magia, Filosofia, Casamento e Poder no Principado Romano, a autora busca enfatizar e analisar os temas que acredita dar subsídios para a sua pesquisa: da magia, da filosofia e do casamento no século II e os seus vínculos com as relações e disputas de poder no Império Romano. Nesta análise, Silva questiona a posição de pesquisadores que refutam a abordagem filosófica de Apuleio e por meio de uma solida discussão bibliográfica, apresenta o papel desempenhado por Apuleio como filósofo médio-platônico. Ainda no capítulo, as práticas mágicas de Apuleio, as relações entre poder e magia, o casamento romano como forma de famílias aristocráticas de Roma contraírem alianças políticas e a situação jurídica e financeira de Pudentila, são refletidas, discutidas e ponderadas pela autora.

É no ultimo capítulo, Acusação e Defesa na Apologia, que consiste na análise detalhada de sua principal fonte, o discurso Apologia. A autora começa citando todos os envolvidos no processo, identifica os pontos de acusação direcionados à Apuleio, para então, agrupá-los em três categorias analíticas que acredita estarem relacionadas aos motivos de acusação: a questão da magia, o papel de Apuleio como filósofo e orador e as acusações relacionadas ao seu casamento com a rica viúva. Para cada categoria é dedicado um subtítulo em que Silva expõe e relaciona, através da analise documental, as motivações, as razões, os conflitos e as relações que se estabeleceram entre Apuleio e os envolvidos no julgamento. Encerra o capítulo com uma investigação minuciosa sobre a estrutura da obra Apologia, na qual é possível compreender que o processo que envolve Apuleio e os seus acusadores é apenas um paliativo das relações e disputas de poder político e financeiro no âmbito do Principado Romano. 
Segundo a própria autora, os estudos historiográficos tradicionais que versam sobre as razões do processo, fundamentam-se em mostrar possíveis confusões dos acusadores em relação às práticas místicas de Apuleio, típicas da filosofia médio-platônica, com a magia e razões de interesse de Apuleio e dos acusadores na riqueza da viúva como causa do processo.

Partindo das inquietações do momento presente, Silva nos apresenta a singularidade de sua pesquisa ao expor uma proposta de leitura das motivações da acusação infligida contra Apuleio no âmbito das relações de poder, em torno de algumas características que envolviam o acusado e que estão, conforme a análise de Silva, presentes na acusação, tais como: a representação do filósofo como homem público capaz de desenvolver atividades relacionadas à política neste contexto, as relações da magia com o poder e a política e os casamentos da elite romana como formas de alianças políticas entre famílias. Elementos que até então não tiveram a devida atenção dos pesquisadores sobre o tema e que trás o diferencial da pesquisa de Silva.

A autora faz uso da História Cultural, como sua abordagem teóricometodológica para realização de sua obra, que fornece subsídios para identificar o modo como em diferentes lugares e momentos uma determinada realidade social é constituída e pensada. O método que é utilizado em sua análise sobre as representações sociais, tem se constituído nos últimos anos como uma das principais formas de investigação histórica.

Em suma, o livro Magia e Poder no Império Romano é voltado para área acadêmica, mas, particularmente, acredito que qualquer pessoa interessada em temas sobre magia, antiguidade e poder, conseguirão reali- 
Cadernos de Clio, Curitiba, n. ${ }^{\circ}$ 4, 2013

zar a leitura sem grandes dificuldades. A obra possui um toque de investigação policial associado ao rigor metodológico da pesquisa histórica que, com isso, faz um convite ao leitor sobre as facetas desse Império, que ainda instiga admiração e curiosidade. 